\title{
Perpustakaan Umum Dengan Pendekatan Arsitektur Hijau Di Kota Magelang
}

\author{
Ridhati Ummi Waskitarini, Edi Pramono Singgih, Tri Yuni Iswati \\ Program Studi Arsitektur \\ Jurusan Arsitektur Fakultas Teknik \\ Universitas Sebelas Maret Surakarta \\ Email : ridhawaskitarini21@gmail.com
}

\begin{abstract}
Designing Public Library Magelang motivated by the low public interest in reading, support the efforts of the government of Magelang in raising interest in reading, as well as the need for educational facilities such as adequate library in Magelang, so the purpose of this architectural planning is to get the design of the educational facilities building that can be means for information needs, education needs and recreation needs for the Magelang society which is the building is able to maintain harmony with the surrounding natural environment. The issue of the design are: how to build a public library of Magelang, that could accommodate the needs of the community reading Magelang. The appearance of this Public Library building based on the principles of Green Architecture. The approach used in determining the design is by using the principles of green architecture based on the standard GREENSHIP Indonesia, which is about the Appropriate Site Development, Energy Efficiency and Conservation, Water Conservation, Material Resources and Cycle, Indoor Health and Comfort, and Building Environment and Management. The result obtained is the design of a municipal public library building with green architecture in accordance with the standards of Indonesian GREENSHIP design consideration so that the existence of the building is expected to maintain harmony with the surrounding nature.
\end{abstract}

Keywords: Architecture, Library, Public Library, Green Architecture

\section{PENDAHULUAN}

Pada era globalisasi sekarang ini, informasi sudah menjadi kebutuhan wajib bagi setiap orang. Cara untuk memenuhi kebutuhan akan informasipun semakin beragam, salah satunya dengan membaca. Minat baca masyarakat Indonesia tergolong masih sangat rendah. UNESCO pada 2012 melaporkan bahwa indeks minat baca warga Indonesia baru mencapai angka 0,001. (Pos Kota News, 2013) Artinya dalam setiap 1.000 orang Indonesia, hanya ada satu orang yang memiliki minat baca. Sedangkan bila dibandingkan dengan negara-negara maju, angka ini terpaut jauh. Sebab rata-rata indeks baca di negara tersebut antara 0.45 sampai dengan 0.62. Kondisi demikian menjadikan minat baca di Indonesia menduduki urutan ketiga dari bawah di dunia (Harian Sindo,2013).

Perpustakaan memiliki peranan yang sangat penting dalam menaikkan minat baca. Dengan fungsinya sebagai sarana penyimpanan, penelitian, pendidikan, informasi dan kultural, keberadaan perpustakaan diharapkan memberikan kontribusi terhadap naiknya indeks minat baca di Indonesia (Suwarno,2010).

Kondisi perpustakaan umum di Kota Magelang yang terletak di Jalan Pahlawan masih belum memadai. Gedung perpustakaan ini pun tidak hanya berfungsi sebagai perpustakaan saja, namun juga sebagai Kantor Arsip dan Dokumentasi Kota Magelang.

Berdasarkan berbagai tinjauan atas, perpustakaan memiliki peranan penting, namun perpustakaan yang ada di Kota Magelang kurang memadai dan kurang dapat mengakomodasi kebutuhan penggunanya, sehingga Kota Magelang dirasa perlu untuk menyediakan fasilitas berupa Perpustakaan Umum Kota Magelang.

Perpustakaan Umum ini direncanakan memenuhi Standar Nasional Perpustakaan Kabupaten/Kota sehingga memerlukan fasilitas penunjang yang dapat dapat 
menunjang sistem pendidikan formal, non formal dan informal serta sebagai sarana pengembangan kreativitas diri anggota masyarakat. Bangunan perpustakaan ini menerapkan konsep desain Arsitektur Hijau yang berdasarkan kaidah GREENSHIP, supaya keberadaannya diharapkan dapat menjaga keselarasan dengan lingkungan alam sekitar.

\section{METODE}

Metode yang digunakan dalam penyusunan konsep perencanaan dan perancangan dibagi menjadi beberapa tahapan :

A. Pengumpulan data, dengan cara survey lapangan dan studi literatur.

1. Survey meliputi:

Survey langsung ke perpustakaan umum.

Observasi lapangan (site observation), merupakan kegiatan pengamatan langsung terhadap kondisi perpustakaan umum.

2. Studi literatur meliputi:

a. Buku-buku, media cetak dan media elektronik yang mendukung tinjauan mengenai perpustakaan dan Arsitektur Hijau.

b. Karya ilmiah (konsep/skripsi) yang telah ada sebelumnya, baik yang terdapat di UNS maupun di luar UNS.

B. Pengolahan data; data dan informasi yang diperoleh melalui survey lapangan dan studi literatur dipilih dan dikelompokkan sesuai tema. Data yang telah dikelompokkan tersebut dipaparkan melalui tinjauan tentang perpustakaan dan segala hal yang berkaitan dengan Arsitektur Hijau, tinjauan kondisi dan potensi Kota Magelang.

C. Pembahasan

Analisa dan sintesa

1. Mengidentifikasikan unsur dan masalah-masalah yang berkaitan serta menunjang tujuan pembahasan.

2. Data dan informasi yang telah diolah menjadi tinjauan, diidentifikasi dan dianalisa untuk mendapatkan konsep perencanaan dan perancangan Perpustakaan Umum Kota Magelang dengan Pendekatan Arsitektur Hijau.

\section{Perumusan Konsep}

Penyusunan hasil analisa ke dalam suatu konsep yang merupakan korelasi antara komponen pembahasan yang hasilnya merupakan bahan dan dasar perancangan fisik pada bangunan Perpustakaan Umum Kota Magelang dengan Pendekatan Arsitektur Hijau.

\section{ANALISIS}

\subsection{Analisis Peruangan}

1. Tujuan: Memperoleh jenis kebutuhan ruang

2. Dasar Pertimbangan: Pengelompokkan kegiatan dan pelaku kegiatan

3. Hasil Analisa:

Konsep analisis pengguna pada Perpustakaan Umum Kota Magelang adalah:
a.Pengunjung
b.Pengelola
c.Petugas Service

Berikut total luasan ruang yang dibuuhkan berdasarkan kelompok kegiatan:

a. Kebutuhan penerima : $110,88 \mathrm{~m}^{2}$

b. Kebutuhan pelayanan perpustakaan: $1500 \mathrm{~m}^{2}$

c. Kebutuhan penunjang : $2084,98 \mathrm{~m}^{2}$

d. Kebutuhan pengelola : $280,18 \mathrm{~m}^{2}$

e. Kebutuhan service $: 1229,83 \mathrm{~m}^{2}$

\subsection{Analisis Pemilihan Lokasi}

1. Tujuan: Mendapatkan lokasi yang sesuai \& mendukung sebagai area didirikannya bangunan perpustakaan dan sesuai dengan GREENSHIP

2. Dasar Pertimbangan:

a. Kriteria menurut peraturan pemerintah daerah

1) Kawasan yang diperuntukkan untuk kawasan pendidikan sesuai dengan tata ruang Kota Magelang

b. Kriteria berdasarkan Standar Nasional Perpustakaan Kabupaten/Kota 
Ridhati Ummi Waskitarini, Edi Pramono Singgih, Tri Yuni Iswati, Perpustakaan Umum dengan ...

1) Berada pada lokasi yang mudah dilihat, dikenal, dan di jangkau masyarakat.

2) Di bawah kepemilikan atau kekuasaan pihak pemerintah daerah.

3) Memiliki status hukum yang jelas.

4) Jauh dari lokasi rawan bencana

c. Kriteria berdasarkan GREENSHIP

1) Memilih daerah pembangunan yang dilengkapi prasarana sarana kota

2) Memilih daerah pembangunan di mana terdapat fasilitas umum dalam jarak pencapaian jalan utama sejauh $1500 \mathrm{~m}$ dari tapak.

3) Memilih lokasi yang dalam radius $300 \mathrm{~m}$ terdapat minimal 3 fasilitas umum dan disediakan akses untuk pejalan kaki menuju ke tempat-tempat tersebut.

4) Memilih lokasi yang berjarak maksimum $300 \mathrm{~m}$ dari gerbang lokasi bangunan ke halte terdekat.

3.Hasil Analisa

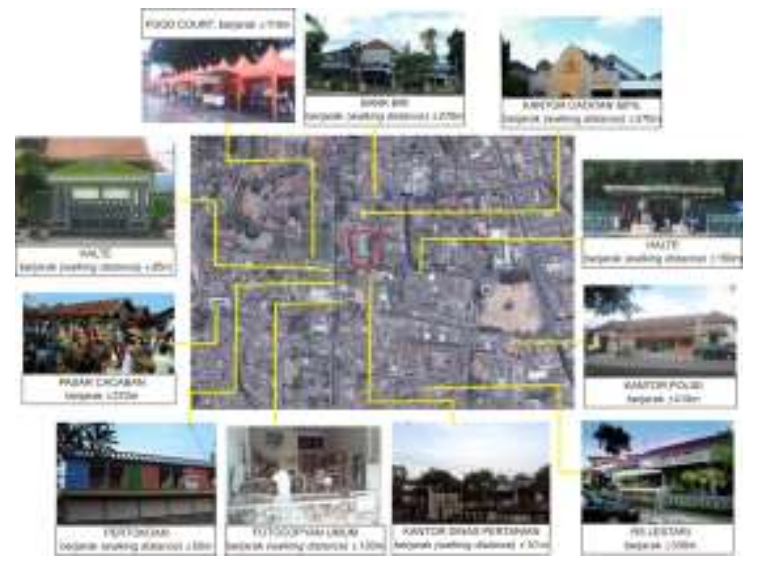

Gambar 1. Analisa Pemilihan Lokasi

\subsection{Analisis Konsep Arsitektur Hijau}

Berdasarkan GREENSHIP

\subsubsection{Analisis Tepat Guna Lahan}

a. Tujuan: memanfaatkan potensi lahan terpilih secara maksimal supaya bangunan yang direncanakan dapat selaras dengan alam sekitar.

\section{b.Dasar Pertimbangan (Kriteria} GREENSHIP)

1) Adanya area lansekap berupa vegetasi (softscape) yang bebas dari struktur bangunan dan struktur sederhana bangunan taman (hardscape) di atas permukaan tanah atau di bawah tanah.

a) Untuk konstruksi baru, luas areanya adalah minimal $10 \%$ dari luas total lahan.

b) Untuk renovasi utama (major renovation), luas areanya adalah minimal $50 \%$ dari ruang terbuka yang bebas basement dalam tapak.

2) Area ini memiliki vegetasi mengikuti Permendagri No 1 tahun 2007 Pasal 13 (2a) dengan komposisi $50 \%$ lahan tertutupi luasan pohon ukuran kecil, ukuran sedang, ukuran besar, perdu setengah pohon, perdu, semak dalam ukuran dewasa, dengan jenis tanaman mempertimbangkan Peraturan Menteri PU No. 5/PRT/M/2008 mengenai Ruang Terbuka Hijau (RTH) Pasal 2.3.1 tentang Kriteria Vegetasi untuk Pekarangan

3) Memilih daerah pembangunan yang dilengkapi minimal 8 dari 12 prasarana sarana kota. Yaitu Jaringan Jalan, Jaringan Fiber Optik, Jaringan penerangan dan Listrik, Danau Buatan (Minimal $1 \%$ luas area), Jaringan Drainase, Jalur Pejalan Kaki Kawasan, STP Kawasan, Pemipaan Gas Sistem Pembuangan Sampah, Jaringan Telepon, Sistem Pemadam Kebakaran, Jaringan Air bersih

4) Terdapat minimal 7 jenis fasilitas umum dalam jarak pencapaian jalan utama sejauh $1500 \mathrm{~m}$ dari tapak. Yaitu Bank, Rumah Makan/Kantin, Taman Umum, Foto Kopi Umum, Parkir Umum (di luar lahan), Fasilitas Kesehatan, Warung/Toko Kelontong, Kantor Pos, Gedung Serba Guna, Kantor Pemadam Kebakaran, Pos Keamanan/Polisi,

Terminal/Stasiun Transportasi Umum, Tempat Ibadah, Perpustakaan, Lapangan Olah 
Raga, Kantor Pemerintah, Tempat Penitipan Anak, Pasar, Apotek

5) Membuka akses pejalan kaki selain ke jalan utama di luar tapak yang menghubungkannya dengan jalan sekunder dan/atau lahan milik orang lain sehingga tersedia akses ke minimal tiga fasilitas umum sejauh $300 \mathrm{~m}$ jarak pencapaian pejalan kaki

6) Membuka lantai dasar gedung sehingga dapat menjadi akses pejalan kaki yang aman dan nyaman selama minimum 10 jam sehari

7) Adanya halte atau stasiun transportasi umum dalam jangkauan $300 \quad \mathrm{~m} \quad$ (walking distance) dari gerbang lokasi bangunan dengan tidak memperhitungkan panjang jembatan penyeberangan dan ramp

8) Adanya area lansekap berupa vegetasi softscape) yang bebas dari bangunan taman (hardscape) yang terletak di atas permukaan tanah seluas minimal $40 \%$ luas total lahan. Luas area yang diperhitungkan adalah termasuk yang tersebut di Prasyarat 1, taman di atas basement, roof garden, terrace garden, dan wall garden, dengan mempertimbangkan Peraturan Menteri PU No. 5/PRT/M/2008 mengenai Ruang Terbuka Hijau (RTH) Pasal 2.3.1 tentang Kriteria Vegetasi untuk Pekarangan.

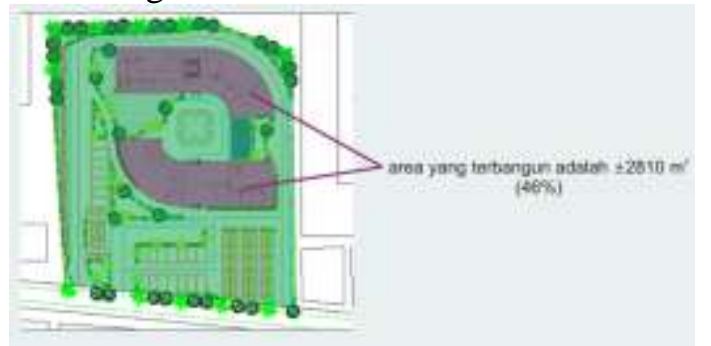

Gambar 2. Analisa Pengolahan Tapak

9) Penggunaan tanaman yang telah dibudidayakan secara lokal dalam skala provinsi, sebesar $60 \%$ luas tajuk dewasa terhadap luas area lansekap pada ASD 5 tolok ukur 1.

10) Menggunakan green roof sebesar $50 \%$ dari luas atap yang tidak digunakan untuk mechanical electrical (ME), dihitung dari luas tajuk.

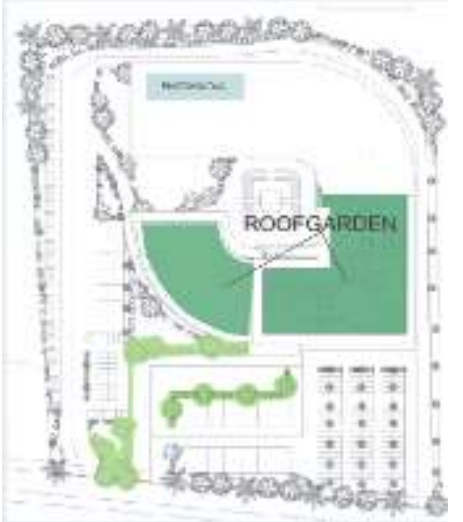

Gambar 3. Analisa Desain Lansekap

11) Desain lansekap berupa vegetasi (softscape) pada sirkulasi utama pejalan kaki menunjukkan adanya pelindung dari panas akibat radiasi matahari.

\subsubsection{Analisis Efisiensi dan Konservasi Energi}

a.Tujuan: menghemat energi pada operasional bangunan, terutama energi listrik.

b.Dasar Pertimbangan (Kriteria GREENSHIP)

1) Memasang $\mathrm{kWh}$ meter untuk mengukur konsumsi listrik pada setiap kelompok beban dan sistem peralatan, yang meliputi: Sistem tata udara, Sistem tata cahaya dan kotak kontak, Sistem beban lainnya

2) Menghitung dengan cara perhitungan OTTV berdasarkan SNI 03-6389-2011 atau SNI edisi terbaru tentang Konservasi Energi Selubung Bangunan pada Bangunan Gedung

3) Menggunakan lampu dengan daya pencahayaan lebih hemat sebesar $15 \%$ daripada daya pencahayaan yang tercantum dalam SNI 03 6197-2011 atau SNI edisi terbaru tentang Konservasi Energi pada Sistem Pencahayaan 
Ridhati Ummi Waskitarini, Edi Pramono Singgih, Tri Yuni Iswati, Perpustakaan Umum dengan ...

4) Penempatan tombol lampu dalam jarak pencapaian tangan pada saat buka pintu.

5) Menggunakan sumber energi baru dan terbarukan. Setiap 0,5\% daya listrik yang dibutuhkan gedung yang dapat dipenuhi oleh sumber energi terbarukan.

6) mendesain pencahayaan alami pada koridor, sehingga mengurangi penggunaan pencahayaan artifisial

\subsubsection{Analisis Konservasi Air}

a. Tujuan: mengontrol penggunaan air sehingga dapat menjadi dasar penerapan manajemen air yang lebih baik

b.Dasar Pertimbangan (Kriteria GREENSHIP)

1) Pemasangan alat meteran air (volume meter) yang ditempatkan di lokasi-lokasi tertentu pada sistem distribusi air, sebagai berikut: Satu volume meter di setiap sistem keluaran sumber air bersih seperti sumber PDAM atau air tanah. Satu volume meter untuk memonitor keluaran sistem air daur ulang. Satu volume meter dipasang untuk mengukur tambahan keluaran air bersih apabila dari sistem daur ulang tidak mencukupi.

2) Konsumsi air bersih dengan jumlah tertinggi $80 \%$ dari sumber primer tanpa mengurangi jumlah kebutuhan per orang sesuai dengan SNI 03-7065-2005

3) Penggunaan seluruh air bekas pakai (grey water) yang telah di daur ulang untuk kebutuhan sistem flushing atau cooling tower.

4) Menggunakan lebih dari satu dari tiga alternatif sebagai berikut: air kondensasi AC, air bekas wudhu, atau air hujan.

\subsubsection{Analisis Sumber dan Siklus Material}

a.Tujuan: menggunakan material yang tidak berbahaya dan mengurangi limbah pembuangan.
b.Dasar Pertimbangan
(Kriteria
GREENSHIP)

1) Tidak menggunakan chloro fluorocarbon (CFC) sebagai refrigerant dan halon sebagai bahan pemadam kebakaran

2) Tidak menggunakan bahan perusak ozon pada seluruh sistem pendingin gedung

\subsubsection{Analisis Kualitas Udara dan \\ Kenyamanan Ruang}

a. Tujuan: menjaga kenyamanan, keamanan dan kesehatan pengguna ruang

b. Dasar Pertimbangan (Kriteria GREENSHIP)

1) Desain ruangan yang menunjukkan adanya potensi introduksi udara luar minimal sesuai dengan Standar ASHRAE 62.1-2007 atau Standar ASHRAE edisi terbaru.

2) Menggunakan lampu dengan iluminansi (tingkat pencahayaan) ruangan sesuai dengan SNI 036197-2011 tentang Konservasi Energi pada Sistem Pencahayaan.

3) Menetapkan perencanaan kondisi termal ruangan secara umum pada suhu $25^{\circ} \mathrm{C}$ dan kelembaban relatif $60 \%$

\subsubsection{Analisis Manajemen Lingkungan}

\section{Bangunan}

a. Tujuan: mencapai sistem pengoperasian bangunan yang ramah lingkungan.

b. Dasar Pertimbangan (Kriteria GREENSHIP)

1) Adanya instalasi atau fasilitas untuk memilah dan mengumpulkan sampah sejenis sampah rumah tangga (UU No. 18 Tahun 2008) berdasarkan jenis organik, anorganik, dan B3 


\subsection{Analisis Pemintakatan}

1. Tujuan: mendapatkan penempatan ruang yang dapat menunjang keefektifitasan fungsi ruang pada bangunan perpustakaan.

2. Dasar Pertimbangan:
aktivitas yang diwadahi.
Berdasarkan aktivitas yang diwadahi terdapat 5 zona, yaitu zona kegiatan pengelola, zona kegiatan servis, zona kegiatan penerima, zona kegiatan penunjang dan zona kegiatan perpustakaan.
b. Kondisi lingkungan sekitar tapak
c. Arah angin
d. Arah sinar matahari
e. Aksesibilitas

3. Hasil Analisa:

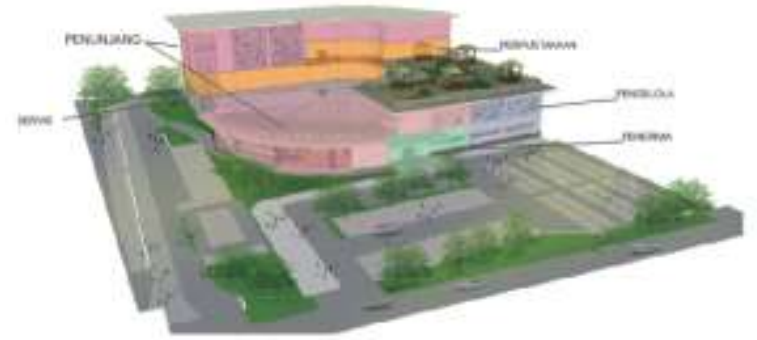

Gambar 4. Hasil Analisa Pemintakatan

a. Zona servis diletakkan pada bagian depan dan belakang sesuai dengan kebutuhan. Seperti tempat parkir dan pos satpam berada di depan sedangkan lainnya di bagian belakang.

b. Zona penerima diletakkan di tengah pada lantai bawah, supaya mudah diakses dari segala arah.

c. Zona pengelola berada pada dekat zona penerima dan zona servis, yaitu terletak pada lantai bawah.

d. Zona perpustakaan diletakkan pada lantai dua (dan di atasnya, sesuai kebutuhan ruang), karena membutuhkan ruangan yang lebih tenang.

e. Zona penunjang yang berisi ruang seminar dan lainnya diletakkan pada bagian atas. Karena penyesuaian dengan struktur bangunan yang memungkinkan minimnya kolom pada lantai paling atas.

\subsection{Analisis Gubahan Massa dan Orientasi Bangunan}

1. Tujuan: mendapatkan gubahan massa bangunan dengan orientasi bangunan yang baik sehingga dapat mewadahi kegiatan di perpustakaan dan dapat menampung semua kebutuhan ruang yang sudah direncanakan

2. Dasar Pertimbangan:

a. Orientasi kegiatan yang ingin diwadahi

b. Mudah dalam pengembangan

c. Fleksibel dalam penataan ruang

d. Kesesuaian dengan bentuk tapak dan komposisinya dengan ruang terbuka

e. Efisiensi dan efektifitas penggunaan tapak, seperti mengenai jumlah cahaya matahari dan angin yang dapat masuk ke dalam bangunan guna memaksimalkan energi alam yang tersedia di sekitar tapak

3. Hasil Analisa:

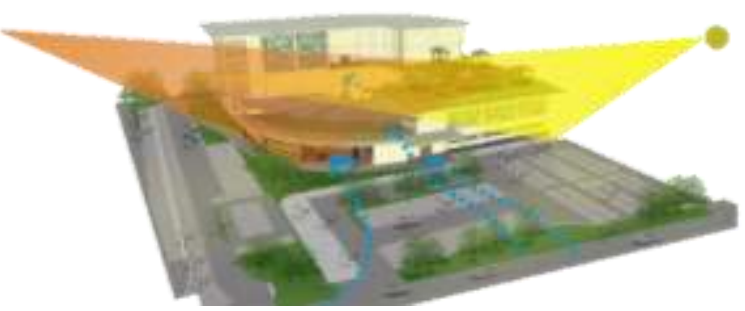

Gambar 5. Hasil Analisa Gubahan Massa dan Orientasi

Bangunan cenderung berbentuk pipih datar guna memaksimalkan potensi alam yang sudah tersedia. Bangunan juga berorientasi utara dan selatan guna meminimalisasi luas permukaan bangunan yang terkena panas matahari.

Bagian depan gedung dibuat lebih rendah, supaya hembusan angin dapat menerus ke gedung bagian belakang.

Bentuk alas bangunan direncanakan berlubang atau berbentuk U, untuk 
Ridhati Ummi Waskitarini, Edi Pramono Singgih, Tri Yuni Iswati, Perpustakaan Umum dengan ...

memungkinkan terciptanya taman tambahan

\subsection{Analisis Kebisingan}

1. Tujuan: menjaga kestabilan tingkat kebisingan di dalam bangunan agar tetap pada batas kenyamanan penggunanya.

2. Dasar Pertimbangan:

Sumber kebisingan dari lingkungan sekitar tapak, peletakkan massa bangunan

3. Hasil Analisa:

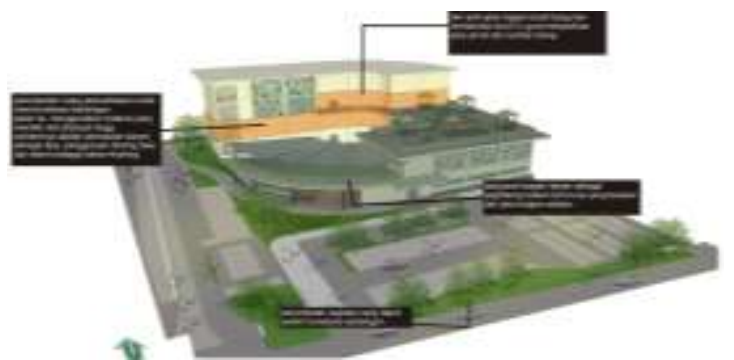

Gambar 6. Hasil Analisa Pengendalian Kebisingan

Menempatkan vegetasi untuk sedikit mereduksi kebisingan dari luar tapak. Massa bangunan dibuat menjadi berbeda ketinggiannya. Bagian depan sebagai penghalang buatan dari bunyi yang berasal dari jalan selatan tapak. Walaupun lebih rendah dari bangunan di belakangnya, namun bangunan tersebut sudah cukup tinggi untuk merefraksi bunyi (bising) dari jalan di selatan tapak.

Menata bangunan berbentuk "U" terhadap jalan di barat tapak, supaya mendapatkan ruang privat yang lebih maksimal.

Menempatkan ruang baca pada bagian pojok bangunan yang merupakan area paling ideal berdasarkan analisa kebisingan supaya dapat menunjang kegiatan membaca para pengunjung perpustakaan.

\subsection{Analisis Lansekap}

1. Tujuan: mendapatkan tata letak vegetasi dan jenis vegetasi yang tepat untuk ditempatkan pada tapak
2. Dasar Pertimbangan: Fungsi dan karakteristik vegetasi, nilai estetika vegetasi, iklim setempat untuk tumbuhnya vegetasi

3. Hasil Analisa:

Mendapatkan pemintakatan jenisjenis vegetasi sesuai dengan fungsi vegetasi.

\subsection{Analisis Struktur Bangunan}

1. Tujuan: memperoleh sistem struktur bangunan yang tepat dalam desain perpustakaan umum Kota Magelang.

2. Dasar Pertimbangan: Bentang ruangruang dalam bangunan sebagai pertimbangan jenis atap, fleksibilitas ruang sebagi pertimbangan lebar bentang dan kolom, prinsip Arsitektur Hijau yang ramah lingkungan

3. Hasil Analisa:

\section{a. Upper structure}

Upper structure merupakan struktur atas. Analisa ini untuk menentukan struktur atap yang tepat bagi bangunan. Sistem struktur yang dipilih adalah: meminimalisir beban angin, dapat dijadikan ruang terbuka.
1) atap datar: dapat
2) atap hijau

b. Supper structure

Supper structure merupakan struktur badan atau tengah. Alternatif Supper structure yang memungkinan adalah sebagi berikut:

1) Struktur rigid kolom dengan bentang $0,7 \mathrm{~m}$

2) Struktur core sebagai perkuatan pada bangunan vertikal.

c. Sub structure

Adalah bagian struktur yang bertindak sebagai dasar/pondasi. Alternatif Supper structure yang memungkinan adalah pondasi umuran. Pondasi sumuran mampu mendukung bangunan dengan ketinggian 1-25 lantai. Dapat digunakan pada jenis tanah berpasir, dimensi yang besar dan banyak membuang tanah galian. 


\section{KESIMPULAN (KONSEP DESAIN)}

Dari hasil analisa serta hasil korelasi dari beberapa data di atas, maka diperoleh hasil berupa desain Perpustakaan Umum Kota Magelang sebagai berikut.

Lokasi : Jl. Kartini, Kota Magelang

Luas Lahan

$$
\text { : } 6023 \mathrm{~m}^{2}
$$

Luas Bangunan : $5000 \mathrm{~m}^{2}$

Jumlah Lantai

$$
\text { : } 4 \text { lantai }
$$

Daya Tampung : 800 orang

Penerapan Arsitektur Hijau pada bangunan Perpustakaan Umum Kota Magelang berdasarkan pada aspek-aspek penilaian dari GREENSHIP, yaitu mengenai ketepatan pengembangan tapak, efisiensi energi dan penghematan energi, penghematan air, sumber material dan daur ulang, kesehatan dan kenyamanan ruang dalam, dan manajemen lingkungan dan bangunan.

Pada bangunan Perpustakaan Umum Kota Magelang ini, konsep Arsitektur Hijau diterapkan dengan memilih tapak berkepadatan tinggi, menambah RTH, orientasi bangunan yang menghadap selatan (lihat lampiran), menambah bukaan untuk pencahayaan, menggunakan material yang aman dan hemat energi serta penggunaan teknologi grey water untuk mengurangi limbah.

\section{REFERENSI}

Suwarno,Wiji. 2010. Pengetahuan Dasar Kepustakaan. Ghalia Indonesia. Bogor

Harian Seputar Indonesia. 19 September 2013. Minat Baca Masyarakat Indonesia Ketiga dari Bawah.

Pos Kota News. 27 September 2013. Minat Baca Warga Indonesia Sangat Rendah.

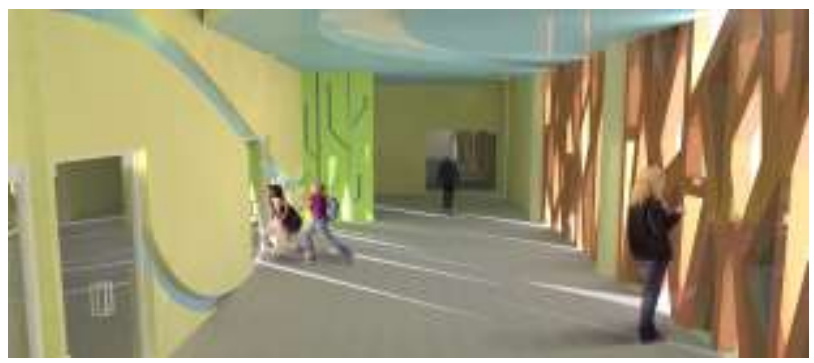

Gambar 7. Selasar Dengan Pencahayaan Alami

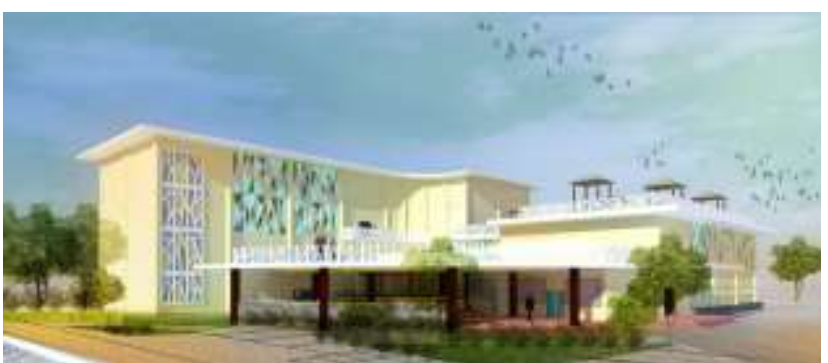

Gambar 8. Eksterior Bangunan 
Ridhati Ummi Waskitarini, Edi Pramono Singgih, Tri Yuni Iswati, Perpustakaan Umum dengan ...

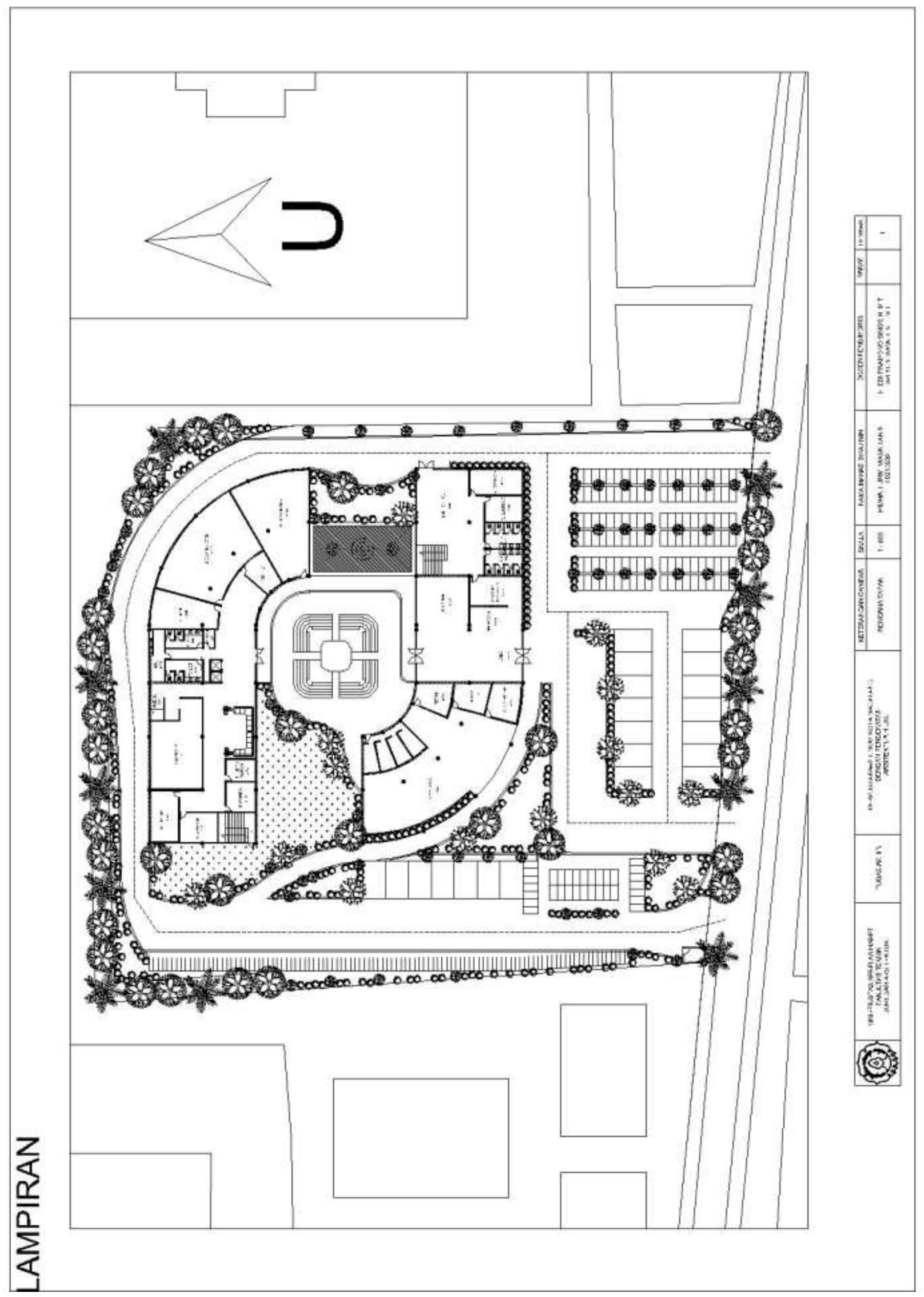

